\title{
Economic Analysis and Mechanization Index of Agricultural Crops in Mandi District of Himachal Pradesh
}

\author{
Shivani Sharma, Ravinder Sharma, Kapil Dev" and Samriti
}

Department of Social Sciences, Dr. Yashwant Singh Parmar University of Horticulture and Forestry, Nauni, Solan, Himachal Pradesh, India

"Corresponding author: sharmakapil2222@gmail.com (ORCID ID: 0000-0003-4049-1134)

Received: $16-12-2020$

Revised: $16-02-2021$

Accepted: 07-03-2021

\begin{abstract}
Economic analysis of agricultural mechanization in mid-hill zone of Himachal Pradesh was conducted in the Mandi district of Himachal Pradesh. The results revealed that the mechanization index at the overall farm category was 0.26 , which varied from 0.21 to 0.53 among different categories of farms. The highest (0.53) farm mechanization index was found in medium farms and the lowest $(0.21)$ in marginal farms. It can further be observed that the coefficient of variation was highest $(39.00 \%)$ in marginal farms and lowest $(6.52 \%)$ in medium farms. At the overall level, 46.15 percent variation was found in farm mechanization.

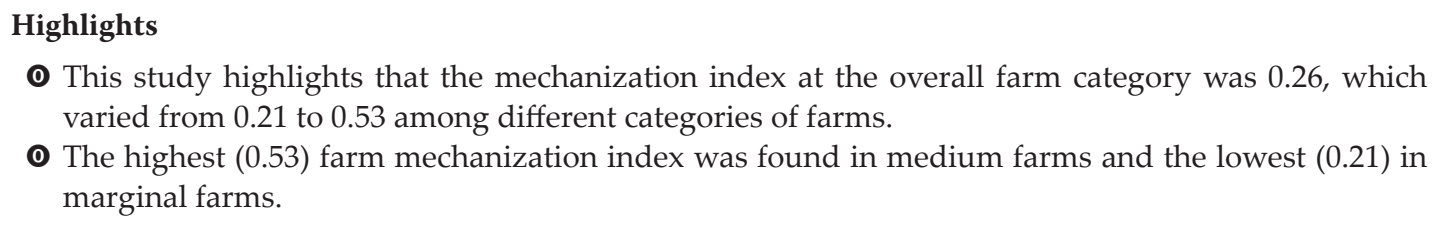

Keywords: Economic analysis, mechanization index, coefficient of variation

Farm mechanization is a key factor in achieving the intended goal by bringing precision, timeliness to farm operations and, at the same time, reducing the hardship of farmworkers. It is one of the main reasons for the country's agricultural growth and overall development. Initially, the role of tools and resources in agriculture became very important because people were involved in different farm activities. As the civilization developed, the styles of instruments and other equipment used in cultivation have also modified through the years. Growth of knowledge, talents, and new technology, results in continuous change in the design of farm machinery and equipment in order to maximize efficiency and thus decrease farm labor. The supply of mechanized farm resources per hectare rose from $0.293 \mathrm{~kW} /$ ha in $1971-72$ to $2.02 \mathrm{~kW} \mathrm{/}$ ha in 2018-19, with a rise of around 52.8 percent, which also encouraged the usage of machines and equipment in agriculture (Anonymous, 2013). Farm mechanization is examined by the increase in the growth of mechanically driven farm machinery over conventional human and animaloperated machinery. The available farm power and productivity in India are expected to reach 2.2 $\mathrm{kW} / \mathrm{ha}$ and $2.3 \mathrm{t} / \mathrm{ha}$, respectively, by the year 2020 (Mehta et al. 2014). In Himachal Pradesh, farm mechanization is restricted to the south-western sub-mountain regions, where land is mostly flat and less undulating. In hilly areas, small tractors, power planters, and sprayers are made available at subsidies to farmers, but mechanization is very limited, and few large farmers use such machines/

How to cite this article: Sharma, S., Sharma, R., Dev, K. and Samriti.
(2021). Economic Analysis and Mechanization Index of Agricultural
Crops in Mandi District of Himachal Pradesh. Economic Affairs, 66(1):
169-174.
Source of Support: None; Conflict of Interest: None 
tools. The extent of farm mechanization in the state in terms of supply of mechanical services as well as machine tools and machinery is comparatively great. In view of these constraints, farmers are mechanizing a few farm development practices, especially in the case of land planning, sowing, harvesting, threshing, etc., as agricultural labor is becoming scarce and expensive due to government job guarantee programs. Hence, it is worth noting that, given the significant increase in available mechanical power and the need-based nature of equipment and facilities, the scale of farm mechanization has not been consistently achieved throughout the length and breadth of the country due to some of the topographical and other relevant factors.

\section{MATERIALS AND METHODS}

Mandi district of Himachal Pradesh was selected purposively for the present study as it has wide variations with respect to topography, elevations, agro-climatic condition, socio-economic and other cultural factors, etc., which directly or indirectly affects the extent of farm mechanization. Multi-stage random sampling was used to select the sample size of 60 farmers from the selected 10 villages of two blocks, namely Gopalpur and Balh, and collection of data has been done from the selected farmers.

\section{Economic analysis}

Cost analysis: CACP concept was used to estimate the cost and returns from agricultural crops cultivation with the following formulae:

(i) Cost $A_{1}$ includes: All material costs + Interest on working capital + Depreciation on implements, farm buildings, and irrigation structures

(ii) $\operatorname{Cost} A_{2}$ : Cost $A_{1}+$ rent paid for leased inland

(iii) Cost $B_{1}$ : Cost $A_{1}+$ interest on the fixed capital

(iv) $\operatorname{Cost} B_{2}$ : $\operatorname{Cost} B_{1}+$ rental value of owned land

(v) Cost $C_{1}$ : Cost $B_{1}+$ imputed value of family labor

(vi) Cost $\mathrm{C}_{2}$ : Cost $\mathrm{B}_{2}+$ imputed value of family labor

(vii) Cost $C_{3}$ (Total cost): Cost $C_{2}+$ value of management input $\left(10 \%\right.$ of $\left.\operatorname{Cost} C_{2}\right)$
Income measure: Following income measures were estimated:

(i) Farm business income $=$ Gross income - Cost $\mathrm{A}_{1}$

(ii) Family labor income $=$ Gross income - Cost $\mathrm{B}_{2}$

(iii) Farm investment income $=$ Farm business income - farm labor wages

(iv) Net income $=$ Gross income - Total cost $\left(\mathrm{C}_{3}\right)$

Crop Yield Index $=$

$\sum \frac{\text { Production efficiency } \times \text { Respected Crop Acreage }}{\text { Total Crop Acreage }}$

Cropping Intensity $=\frac{\text { Gross cropped area }}{\text { Net sown area }} \times 100$

$$
\text { Coefficient of Variation }=\frac{\text { Standard deviation }}{\text { Mean }} \times 100
$$

\section{Index of Agricultural mechanization}

Iyengar and Sudarshan's (1982) methodology was used for the development of a composite index of farm mechanization. Major and minor farm implements were used as goal variables to assess the farm mechanization index.

It is assumed that $\mathrm{n}$ is the number of farmers, $\mathrm{K}$ indicates it implement investment viz. major implements (plow, tractor, power tiller, chaff cutter, thresher, water pump, foot sprayer, power sprayer) and minor implements (spade, sickle, pickaxe, rake, hoe, ax, grafting knives, plankers, plastic crates) and $x_{i j^{\prime}} i=1,2 \ldots, n ; j=1,2 \ldots . K$ are the normalized scores. The level of farm mechanization index of $i^{\text {th }}$ treatment, $i$, is assumed to be a linear sum of $x_{i j}$ as,

$$
\begin{aligned}
& \underline{y}_{i}=\sum_{j=1}^{k} w_{j} x_{i j} \\
& w_{j}=\frac{c}{\sqrt{\operatorname{var}_{i}\left(x_{i j}\right)}}
\end{aligned}
$$

Where $w^{\prime}{ }_{j}$ is the weights assumed to vary inversely to the variance over the different farm implements in the respective indicators of farm implements investment. 


$$
c=\left[\sum_{j=1}^{j=k} \frac{1}{\sqrt{\operatorname{var}_{i}\left(x_{i j}\right)}}\right]^{-1}
$$

Where; $c$ is a normalizing constant

The choice of the weights in this manner would ensure that large variation in any one of the indicators would not unduly dominate the contribution of the rest of the indicators and distort farm categories wise comparisons. The index of farm mechanization so computed lies between 0 and 1, with 1 indicating best farm mechanization and 0 indicating least farm mechanization.

\section{RESULTS AND DISCUSSION}

\section{General Information of the study area}

General information about study areas has been given in Table 1. General information covered gross area, cultivated area, irrigated area, cropping intensity, crop yield index, coefficient of variation, agriculture workers, tractor, power tiller, chaff cutter, thresher, water pump, foot sprayer, power sprayer. Gross copped area was found highest in the medium farms (2.61 ha) followed by small farms (2.06 ha) and marginal farms (0.84 ha). The average gross area in the overall farm category was found 1.33 ha. The overall cultivated area was 1.2 ha ranging between 2.45 ha to 0.76 ha from medium to marginal farmers.

\section{Economic analysis of major crops}

Economic analysis in terms of the total cost, farm business income, farm labor income, gross income, net income, benefit-cost ratio (BCR), and yield (q/ ha) was analyzed for the major crops grown in the study area have been presented farm category-wise in Table 2.

\section{Paddy}

Total cost $\left(\mathrm{C}_{3}\right)$ incurred in the cultivation of paddy was highest on medium farms ( $₹ 71485.36 /$ ha) and lowest on marginal farms (₹ 60784.56/ha). Analysis of gross income of paddy showed an income of ₹ 89550.30 at an overall level in the study area. It was found highest on medium farms (₹ 99182.80/ ha) and lowest on marginal farms (₹ 86880.46/ha), whereas the farm business income and farm labor income was highest on marginal farms (₹ 48784.60/ ha) and medium farms (₹ 41610.87/ha), respectively. At the overall level, these incomes were ₹ 47916.60, ₹ 40205.42 per hectare, respectively, in the study area. Net income varied from ₹ 26095.90 to $₹ 27697.43$ under different farm categories. Overall, BCR was 1.42 while found highest as 1.43 on marginal farms and lowest as 1.38 on small farms.

Table 1: General Information of the study area

\begin{tabular}{|c|c|c|c|c|}
\hline Particulars & Marginal & Small & Medium & Overall \\
\hline Average size of holding & 0.78 & 1.93 & 2.67 & 1.27 \\
\hline Gross cropped area, ha & 0.84 & 2.06 & 2.61 & 1.33 \\
\hline Cultivated area, ha & 0.76 & 1.82 & 2.45 & 1.20 \\
\hline Irrigated area, ha & 0.65 & 1.77 & 2.45 & 1.11 \\
\hline Cropping intensity (\%) & 111.06 & 113.40 & 106.66 & 110.50 \\
\hline Crop yield index (\%) & 125.63 & 128.67 & 142.27 & 128.05 \\
\hline Coefficient of variation (\%) & 11.45 & 7.78 & 5.32 & 9.92 \\
\hline No. of agriculture workers & 97.00 & 33.00 & 18.00 & 43.86 \\
\hline No. of Cow, ACU & 0.64 & 0.44 & 0.50 & 0.58 \\
\hline No. of Buffaloes, ACU & 0.83 & 0.81 & 1.30 & 0.87 \\
\hline No. of Bullocks, ACU & 0.36 & 0.75 & 1.33 & 0.55 \\
\hline No. of Tractor & 7.00 & 11.00 & 5.00 & 7.80 \\
\hline No. of Power tiller & 10.00 & 3.00 & 1.00 & 7.35 \\
\hline No. of Chaff cutter & 40.00 & 16.00 & 8.00 & 30.80 \\
\hline No. of Thresher & 4.00 & 3.00 & 2.00 & 3.55 \\
\hline No. of Water pump & 53.00 & 21.00 & 13.00 & 41.00 \\
\hline No. of Foot sprayer & 9.00 & 4.00 & 2.00 & 7.05 \\
\hline No. of Power sprayer & 5.00 & 3.00 & 2.00 & 4.20 \\
\hline
\end{tabular}


Table 2: Financial analysis of different crops in the study area

\begin{tabular}{lllllllll}
\hline $\begin{array}{l}\text { Farm } \\
\text { Category }\end{array}$ & Crops & Total Cost & $\begin{array}{l}\text { Yield } \\
\text { (qt1/ha) }\end{array}$ & \multicolumn{2}{l}{$\begin{array}{l}\text { Farm Business } \\
\text { income }\end{array}$} & $\begin{array}{l}\text { Farm Labour } \\
\text { income }\end{array}$ & $\begin{array}{l}\text { Gross } \\
\text { Income }\end{array}$ & Net Income BCR \\
\hline Marginal & Paddy & 60784.56 & 46.96 & 48784.60 & 39862.76 & 86880.46 & 26095.90 & 1.43 \\
Small & & 66469.40 & 50.08 & 45985.49 & 40534.15 & 92638.86 & 26169.45 & 1.38 \\
Medium & & 71485.36 & 53.61 & 47102.38 & 41610.87 & 99182.80 & 27697.43 & 1.39 \\
Overall & & 63275.85 & 48.41 & 47916.60 & 40205.42 & 89550.30 & 26274.44 & 1.42 \\
Marginal & \multirow{2}{*}{ Wheat } & 45318.92 & 35.19 & 38197.47 & 30981.28 & 68086.17 & 22767.25 & 1.50 \\
Small & & 47779.56 & 37.49 & 40571.68 & 34856.36 & 72540.00 & 24760.44 & 1.52 \\
Medium & & 43119.40 & 42.24 & 51136.11 & 47585.19 & 81729.45 & 38610.05 & 1.90 \\
Overall & & 45714.13 & 36.47 & 40084.89 & 33610.44 & 70563.96 & 24849.83 & 1.55 \\
Marginal & \multirow{2}{*}{ Maize } & 97651.92 & 62.76 & 67282.04 & 38417.27 & 114536.20 & 16884.28 & 1.17 \\
Small & & 98909.42 & 62.52 & 61253.39 & 36793.00 & 114102.98 & 15193.56 & 1.15 \\
Medium & & 88401.93 & 61.72 & 54630.65 & 44882.15 & 112645.35 & 24243.42 & 1.27 \\
Overall & & 97041.30 & 62.60 & 64509.74 & 38657.69 & 114238.81 & 17197.51 & 1.18 \\
Marginal & \multirow{2}{*}{ Tomato } & 161439.55 & 151.37 & 430545.04 & 404490.11 & 529787.48 & 368347.94 & 3.28 \\
Small & & 176987.98 & 138.69 & 358047.77 & 346035.41 & 485415.34 & 308427.36 & 2.74 \\
Medium & & 221630.75 & 171.37 & 442963.61 & 419782.86 & 599798.39 & 378167.64 & 2.71 \\
Overall & & 171345.77 & 150.20 & 413662.58 & 391405.71 & 525695.54 & 354349.76 & 3.09 \\
\hline
\end{tabular}

\section{Wheat}

Total cost $\left(\mathrm{C}_{3}\right)$ for the cultivation of wheat was highest on small farms (₹ 47779.56/ha) and lowest on medium farms (₹ 43119.40/ha). The gross income of wheat was found ₹ 70563.96 at an overall level in the study area. It was found highest on medium farms (₹ 81729.45/ha) and lowest on marginal farms (₹ 68086.17/ha), whereas the farm business and farm labor income was highest on medium farms (₹ 51136.11 and ₹ 47585.19 respectively). Net income of wheat varied from $₹ 22767.25$ to $₹ 38610$ under different farm categories, with an overall income of ₹ 24849.83 in the study area. Overall, BCR was 1.55 while found highest as 1.90 on medium farms and lowest as 1.50 on marginal farms.

\section{Maize}

Total cost $\left(\mathrm{C}_{3}\right)$ was highest on marginal farms (₹ 98909.42/ha) and lowest on large farms (₹ 88401.93/ha). The gross income of maize, was $₹ 114238.81$ at an overall level in the study area and was found highest on marginal farms (₹ 114536.20/ ha) and lowest on medium farms (₹ 112645.35/ha). As a result, the farm business income is estimated highest on marginal farms ( $₹$ 67282.04/ha), and farm labor income is estimated highest on medium farms (₹ 44882.15/ha). Net income varied from ₹ 15193.56 to ₹ 24243.42 under different farm categories with an overall income of ₹ 17197.51 per hectare with BCR of 1.18 in the study area.

\section{Tomato}

Total cost $\left(\mathrm{C}_{3}\right)$ varied from ₹ 161439.55 (marginal farms) to ₹ 221630.75 (medium farms) per hectare in the study area. The gross income of tomato, was found ₹ 525695.54/ha at an overall level in the study area and varied from small farms ( $₹ 48541.34$ ) to medium farms (₹ 599798.39). It was found that the farm business income and farm labor were highest on medium farms (₹ 442963.61/ha), whereas farm labor income was highest on medium farms (₹ 419782.86/ha) respectively. At the overall level, these incomes were worked out to be ₹ 413662.58 and ₹ 391405.71 per hectare in the study area. Net income varied from ₹ 308427.36 to ₹ 378167.64 under different farm categories with an overall net income of ₹ 354349.76 with a BCR of 3.09 in the study area.

\section{Mechanization Index}

In every farm settlement, the practice of selective machinery was prominent. Only tillage operations such as ploughing were restricted to mechanical operations. Other operations were done manually, such as planting, weeding, applying fertilizers, and harvesting. This is due to the poor standardization and lack of mechanization inputs to serve the entire 
Table 3: Mechanization Index for different farm categories in the study area

\begin{tabular}{lllll}
\hline Mechanization index & Mean & Standard Deviation & CV \\
\hline \multirow{3}{*}{ Marginal } & Major Implements & 0.15 & 0.06 & 40.38 \\
& Minor Implements & 0.28 & 0.13 & 46.99 \\
& Total & 0.21 & 0.08 & 39.00 \\
\multirow{3}{*}{ Small } & Major Implements & 0.25 & 0.08 & 33.27 \\
& Minor Implements & 0.24 & 0.06 & 24.42 \\
\multirow{4}{*}{ Medium } & Total & 0.25 & 0.06 & 24.38 \\
& Major Implements & 0.61 & 0.05 & 8.45 \\
& Minor Implements & 0.46 & 0.02 & 5.31 \\
\multirow{3}{*}{ Overall } & Total & $0.53^{*}$ & 0.03 & 6.52 \\
& Major Implements & 0.28 & 0.16 & 57.14 \\
& Minor Implements & 0.22 & 0.13 & 59.09 \\
\hline
\end{tabular}

* indicates moderately farm mechanization.

production scale. The farm mechanization index was estimated and classified as:

- 0 - Non-farm mechanized

- $>0.5$ - Highly farm mechanized

- 0.5 - Moderately farm mechanized

- $<0.5$-Less farm mechanized

The results have been presented in Table 3, which revealed that the mechanization index at the overall farm category was 0.26 , which varied from 0.21 to 0.53 among different categories of farms. The highest (0.53) farm mechanization index was found in medium farms and the lowest (0.21) in marginal farms. It can further be observed that the coefficient of variation was highest (39.00\%) in marginal farms and lowest $(6.52 \%)$ in medium farms. At the overall level, 46.15 percent variation was found in farm mechanization. Farm mechanization index at the overall farm level with respect to minor implements (0.28) was higher in marginal farms, which revealed more dependence on minor implements compared to major implements. However, on the small farm, the difference between minor and major implements was negligible. In medium farms mechanization index for major implements (0.61) was higher compared to the mechanization index (0.46) of minor implements.

Agricultural mechanization has been identified as one of the critical inputs for increasing the productivity of the land by ensuring timeliness of agricultural operations, increased labor work output per unit time by reducing efforts and drudgery, and improved the quality of farm operations. Farm mechanization index at overall farm category was found 0.26 , which varied from 0.21 to 0.53 among different categories of farms. The highest (0.53) farm mechanization index was found in medium farms and the lowest (0.21) in marginal farms. The variation was found in farm mechanization and was highest $(39.00 \%)$ in marginal farms and lowest $(6.52 \%)$ in medium farms. At the overall level, 46.15 percent variation was found in farm mechanization in the study area. Mechanization may get momentum with the adoption of tractors, power tillers, power-operated sprayer duster for spraying/dusting, and track-type combine harvester for harvesting. The growth of farm mechanization in the state as well as in the Mandi district is slow in the light of existing policies and incentives of the state government. Therefore, it is suggested that the state government should increase the existing level of subsidy on farm machinery and implements, especially in the case of tractors and power tillers.

\section{REFERENCES}

Anonymous. 2013. Directorate of Economics and Statistics, Department of Agriculture and Cooperation, Ministry of Agriculture, New Delhi, pp. 221.

Ferdous, J. and Masud, M.B. 2011. Farm mechanization in Bangladesh: an overview. Int. J. Sustain. Agric. Technol., 7: 1-7. 
Iyengar, N.S. and Sudarshan, P. 1982. A Method of classifying regions from Multivariate Data. Eco. Pol. Weekly, 1-5.

Jangid, B.L., Intodia, S.L. and Regar, P.L. 2010. Status of farm power and machinery and promotion of farm mechanization in Southern Rajasthan. Agric. Eng. Today, 34: $18-23$.

Kumar, S. 2014. Study on the agricultural mechanization in Karimnagar district of Andhra Pradesh. M.Sc. Thesis. Department of Agricultural Extension: Acharya N.G Ranga Agricultural University, Rajendernagar, Hyderabad.

Mc Nulty, P.B. and Grace, P.M. 2009. Agricultural Mechanization and Automation. Agricultural and Food Engineering Department, National University of Ireland. Encyclopedia of Life Support system UNESCO, Paris, 1: 5-10.

Mehta, C.R., Chandel, N.S. and Senthil Kumar, T. 2014. Status, challenges and strategies for farm mechaninization in India. J. Article-Agriculture Mechanization in Asia Africa and Latin America, 45(4): 43-50.

Mishra, D.K., Pandey R.N. and Pandey V.K. 1976. Economic costs of bullock and tractor power use in Uttar Pradesh agriculture. Indian J. Agric. Econ., 31: 193.
Namdeo, A. 2016. Status of farm mechanization under animal farming system in Chhattisgarh. M Sc. Thesis. Indira Gandhi Krishi Vishwavidyalaya, Raipur, India

Singh, G. 2006. Estimation of a Mechanization Index and Its Impact on Production and Economic Factors - a Case Study in India. Biosystems Engg., 93(1): 99-106.

Singh, R.S. and Kumar, M. 2017. Economic evaluation and mechanization index of selected cropping pattern in Madhya Pradesh. Eco. Affa., 62(3): 439-446.

Singh, S.P., Singh, R.S. and Singh, S. 2011. Sale trend of tractors and farm power availability in India. Agric. Engg. Today, 35: 25-35.

Vinay, S.B. 2014. Economic analysis of farm mechanization in Maharashtra. M.Sc. Thesis. Mahatma Phule Krishi Vidyapeeth, Rahuri.

Yadav, S., Bahl, V.P. and Bhalla, D. 1999. Utilization pattern of farm tractors in district Mohindergarh (Haryana). Agric. Engg. Today, 23: 65-76.

Zaren, Y. and Isik, A. 1991. Agricultural inputs, mechanization and employment in Turkey. Agric. Mecha. Asia, Africa and Latin, 4: 25-32. 